\title{
Adoption of Modern Bee Hive in Arsi Zone of Oromia Region: Determinants and Financial Benefits
}

\author{
Tamrat Gebiso \\ Oromia Agricultural Research Institute, Asella Research Center, Asella, Ethiopia \\ Email: tameulove@yahoo.com
}

Received 5 March 2015; accepted 22 March 2015; published 27 March 2015

Copyright (C) 2015 by author and Scientific Research Publishing Inc. This work is licensed under the Creative Commons Attribution International License (CC BY). http://creativecommons.org/licenses/by/4.0/

\section{(c) (i) Open Access}

\section{Abstract}

Arsi zone is one of the Oromia regional state's zones with high potential of honey and bees wax production and where there was dissemination of modern beehives. This research was initiated with objectives of quantifying adoption rate of modern beehives and its determinant factors and drawing policy implication for further extension of the technology. The study was conducted in seven districts of Arsi zone and 251 rural beekeepers were interviewed. The average productivity of the modern beehives and local beehives was found to be $19.77 \mathrm{~kg} / \mathrm{hive}$ and $5.13 \mathrm{~kg} / \mathrm{hive}$. The total number of local bee hives possessed by interviewed beekeepers was found to be 1201 while that of modern beehives was found to be $\mathbf{2 7 9}$ hives which shows that the adoption rate is low and if we increase the adoption rate by $50 \%$, the amount of honey harvest will increases by $11,862 \mathrm{~kg}$ which is about $5700 \mathrm{~kg}$ more than the total honey beekeepers can get from keeping the whole 1201 local hives. Chemical application (herbicides and pesticides), bee predators, lack of knowledge and skill on modern beehives, lack of modern beehive accessories, lack of bee forage and lack of capital were major beekeeping bottlenecks. The result of binary Logit model revealed that the main determinants of adoption are farmyard size, number of local hives beekeepers possessed, training provided, participation on demonstration, wealth status of beekeepers, and participation of beekeepers on nonfarm income sources. Provision of different information towards increasing or improving the saving capacity or culture of beekeepers, provision of adequate and relevant agricultural extension services (such as training on modern beekeeping technologies and experience sharing among beekeepers), provision of credit services to widen the financial bases of poor beekeepers and facilitating access to modern beehives and its accessories especially honey extractor and wax stumper which can increase beehives productivity were the recommendation that was drawn from the output of this research.

\section{Keywords}

Adoption, Modern Beehives, Logit Model, Adopters, Non-Adopters, Beekeepers 


\section{Statement of the Problem}

Ethiopia, with around $23.6 \%$ of African and $2.1 \%$ of the world production, is the leading honey producer in Africa and is one of the ten largest producers in the world [1]. It is also one of the four largest beeswax producing countries in the world following China, Mexico and Turkey. In Ethiopia, beeswax is one of the 12 major exportable agricultural products and an estimated one million farmers are engaged in beekeeping [2]. The country produces about 28,500 tons of honey and $5000 \mathrm{t}$ of beeswax annually [3].

As it is known traditional way of beekeeping is practiced throughout the country in general and in Oromia specifically by hanging the traditional hive over the long trees which is very difficult for management and harvesting or putting the hive under their roof at the outside. This way of beekeeping, especially by hanging over the long tree in the forest is not convenient for female farmers. With all other its problems traditional beehive additional problem of low productivity with production per hive averaging 5 - $6 \mathrm{~kg}$ compared to modern beehives which has average production of 15 - $20 \mathrm{~kg} / \mathrm{hive}$ and even more [3].

By realizing the potential of apiculture subsector and the problem associated to traditional beehive, Ethiopian government tried to introduce different beekeeping technologies to beekeepers. For instance the establishment of beekeeping demonstration stations at different areas like Holeta, Nekemte, and Jimma etc. in 1965 to introduce improved beekeeping technologies (box hives, casting mold, honey extractor, honey presser, smoker, water sprayer, veil, glove etc.) imported from abroad to the beekeepers and to offer beekeeping training for farmers and experts can be mentioned [3].

Oromia region having large share of honey production of the country, with about $41 \%$ of total country's production, the regional government disseminated considerable number of modern (box) hives to farmers which are produced by different regional agricultural mechanization research centers and different private microenterprises in 2001/02.

Arsi zone is one of the Oromia regional state's zones with high potential of honey and bees wax production and one of the Zones where there was dissemination of modern beehives on cash and credit basis from AAMRC and private microenterprises and having potential suppliers of the modern hive. However, there is no adequate information on the adoption status and determinant factors such as socioeconomic, economic and socio-psychological factors of the adoption for this technology. Therefore, the socioeconomics, demographic and other technical factors that affect adoption and utilization of this technology has to be identified and this research proposal was initiated for this reason.

\section{Objectives of the Study}

The general objective of this study is to assess the level of adoption of modern beehives with its determinant factors in Arsi zone while the specific objectives of the research are:

1) To quantify adoption rate of modern beehives in Arsi zone;

2) To identify the determinant factors that affect adoption of modern beehives;

3) To draw policy implication for further extension of modern beehives in the study areas.

\section{Literature Review}

\subsection{Definition and Concept of Adoption}

Adoption was defined by Feder, et al. [4] as degree of use of new innovation by a farmer when he has got full information about the new innovation and its potentials. The author classified adoption of new technology into two as individual and aggregate adoption. Accordingly, they defined Individual adoption as the farmer's decisions to incorporate a new technology into the production process and the aggregate adoption as the process of diffusion of a new technology within a region or population. Furthermore, Rogers and Shoemaker [5] defined technology adoption as the decision made by a farmer to use a new technology as best course of action he ever practiced. Adoption of new technology in agriculture which occurs due to behavioral changes like desirable changes in knowledge, understanding and ability to apply technological information, changes in feeling behavior such as changes in interest, attitudes, aspirations, values and the like; and changes in overt abilities and skills, is determined by many socio-economic factors [6] [7].

Adoption is not a simple and overnight activity, but it is a mental process which an individual farmer (decision- 
maker or group of decision maker's family members) goes through for decision-making. To ensure adoption of new innovation the fulfillment of specific economic, technical and institutional conditions are required. From the farmers' perspective, the new technology should be economically more profitable than the existing alternatives. Moreover, the new technology should also be technically easily manageable by small holders and adaptable to the surrounding socio-cultural situations and availability of the new technology and all other necessary inputs to small holders at the right time and place and in the right quantity and quality are necessary conditions [8]. In general adoption is a function of five characteristics of the technology which are relative advantage or profitability, compatibility or riskiness, complexity, triability/divisibility, or initial capital requirements, and observability or availability [5] [9].

\subsection{Empirical Review of Determinants for Adoption of Modern Beehives}

Past studies have documented some demographic and socioeconomic factors that influenced the adoption of different technologies among smallholder farmers in developing countries. Studies by Croppenstedt et al. [10] in Ethiopia and Naseem et al. [11] in sub-Saharan Africa identified plot size, previous experience with fertilizer, supply of fertilizer, farm size, amount of rainfall, household size, and the ratio of price of main crop to cost of fertilizer as well as accessed to credit as factors constraining fertilizer demand among arable crop farmers. Feder et al. [4] in their research report stated that credit, farm size, risk, labor availability, and human capital, land tenure and education are main factors affecting technological adoption. Cramb [12] inferred that different demographic and socioeconomic characteristics of farm-household are associated with technology adoption such as: age, education and personal characteristics of the household head; size, location and tenure status of the farm; availability of cash or credit for farm investment and access to markets for farm produce; and so on. The study done on adoption and profitability of Kenya Top Bar beehive which may be the first study in Ethiopia, by Melaku [13], evidenced that household farm experience, perception of timely supply of the technology, extension contact, and visit to apiaries are major adoption determinants. Workineh [14], also found that credit, Knowledge on practical activities of the technology, education level of household head, positive perception on modern beehive technologies and apiary visit demonstration were most determinant factors of adoption of improved box hive.

\section{Research Methodology}

\subsection{Description of the Study Area}

The study was conducted in Arsi Administrative zone, South-Eastern part of Oromia Regional State. Arsi zone is one of the 22 zones of the Oromia National Regional State. It is located in the southeastern part of the country. It is also situated between $6^{\circ} 45^{\prime} \mathrm{N}$ to $8^{\circ} 58^{\prime} \mathrm{N}$ latitude and $38^{\circ} 32^{\prime} \mathrm{E}$ to $40^{\circ} 50^{\prime} \mathrm{E}$ longitude [15]. It has a surface area of about $23,881 \mathrm{~km}^{2}$ and characterized by mixed farming system. The variation in its altitude enables Arsi zone to have different agro-ecological zones (mainly five major zones) of which moderately cold one accounts for about $40 \%$ of the total followed by cool annual temperature accounting for about $34 \%$ of the total area of the zone. In general, the mean annual temperature of the Zone ranges between $20^{\circ} \mathrm{C}-25^{\circ} \mathrm{C}$ in the low land and $10^{\circ} \mathrm{C}$ $15^{\circ} \mathrm{C}$ in the central high land [16]. It is also known for its surplus production and knows as wheat-belt of Ethiopia [17].

\subsection{Sampling Techniques}

Arsi zone is the study area which is purposively selected because of the economic importance of beekeeping, potential dangers of different agricultural practices like deforestation, chemical application for apiary activities and the efforts so far done by governments and nongovernmental bodies. Both multi-stage and purposive sampling techniques were employed where seven districts were selected based on their agro-climatic condition and apiary potentials purposively. Accordingly, Amigna, Bele, Arsi-Robe, Lode-Hetosa, Chole, Merti and LemuBilbilo were selected. Then based on beekeeping potential, two PAs were selected from each district and finally, forty beekeepers from each PA which makes the total respondents 280 were selected for the formal interview. But twenty nine respondents were not contacted because of their absence and two hundred fifty one (251) beekeepers were interviewed. 


\subsection{Method of Data Collection}

Primary data were employed in this research and the data were collected primarily from beekeepers through interview and focus group discussion. Preliminary survey was conducted to assess the potentials of each district in beekeeping and the potential challenges of beekeeping in the study area. At the second stage formal survey was conducted by structured questionnaires. Focus group discussion was also conducted with key informants from beekeepers, development agents and district level beekeeping (livestock) experts.

\subsection{Method of Data Analysis}

In addition to the descriptive and inferential statistics, econometric model called binary logit was employed. In most adoption studies, the use of dichotomous models like probit and logit, are common as the case of LPM use, the probability may not lie between 0 and 1 . Even though there exist statistical similarity between the outputs of logit and probit models, Aldrich and Nelson [18], but logit model is easier to estimate. The objective of binary logit model was to estimate the probability of a household to adopt or not to adopt modern beehive. The dependent variable is dichotomous and therefore, following Gujarati [19], the binary logit model is specified as follows:

$$
Y_{i}=\beta_{0}+\beta_{1} X_{1}+\cdots+\beta_{12} X_{12}+\varepsilon
$$

where;

$X_{i}$, is the vector of independent variables representing a number of demographic and socioeconomic variables of $i^{\text {th }}$ beekeeper. The dependent variable $Y_{i}$, is equal to 1 if the beekeeper adopted modern beehive and zero otherwise. The above Equation (1) can be interpreted as describing the probability that a given beekeeper is deciding to adopt the modern beehive. The value of the parameters, $\beta$, measures the marginal impact of a unit change in the explanatory variables on the probability of technology adoption.

The above linear model can be transferred into a cumulative probability function as follow, mainly to avoid the potential errors of having the predicted values, $Y_{I}$ falling outside the $(0,1)$ range.

$$
\rho_{I}=F\left(X_{i} \beta\right)
$$

If the cumulative probability function $F($.$) is logistic, then we have the logit model of the form:$

$$
\rho_{i}=\frac{1}{1+\mathrm{e}^{-X_{i} \beta}}
$$

The marginal effect of a particular variable on the probability that a particular household decide to adopt is given by:

$$
\frac{\partial \rho_{i}}{\partial X_{i}}=f(X \beta) \beta_{k}^{\prime}
$$

where $f($.$) is the logistic density function given by:$

$$
f\left(X^{\prime} \beta\right)=\frac{\mathrm{e}^{-X^{\prime} \beta}}{\left(1+\mathrm{e}^{-X^{\prime} \beta}\right)^{Z}}
$$

\subsection{Hypotheses and Definition of Variables}

Age of respondents (Age): It is hypothesized that age negatively affects adoption.

Educational background: categorical 0 = illiterate, 1 = literate

Credit use: use of credit can solve problem of capital shortage for the investment and is expected to enhance adoption of the modern beehive (dummy; 1 = user and 0 otherwise). In this case since the credit from government bodies is ear tagged for agricultural inputs like chemical fertilizer and seed, only credit utilization from other sources was considered

Number of local beehive: this variable is also expected to have positive impact on adoption probability of the technology assuming as farmers saw the little advantages from local hive they may think of improving their advantage from the beekeeping activity (continuous count).

Sex of respondents: being female is assumed to expose to different cultural discrimination from large society 
and excluded from different extension services and have negative impact on adoption probability (dummy; 1 = male and $0=$ female)

Training on beekeeping: it is dummy variable; 1 = yes 0 otherwise

House stead land size (farm yard in ha): unless beekeeping activity is not commercialized so far the farmers are expected to practice apiary in their farm yard/house stead and as the farm yard size increases it is expected to have more probability of adoption (continuous).

Family labor (man equivalent): it is expected that as family size increases the adoption probability increase to utilize the family labor (continuous number).

Livestock (TLU) is expected to have either negative or positive impact

Farm size (ha): it is expected that farm size of the farmer enhance the adoption

Participation on nonfarm income source (it is dummy variable; 1 = yes 0 otherwise):

Participation on demonstration of modern beehives (it is dummy variable; 1 = yes 0 otherwise): it is hypothesized that it has positive effect.

Total Income: it is the sum of all income in birr that a beekeeper gets from sale of crop, livestock, honey and other nonfarm sources. It is continuous variable measured in Ethiopian birr.

Type of house of household (htype dummy, 1 = if house is thatched roof; 0 otherwise).

\section{Result and Discussion}

\subsection{Demographic and Socio-Economic Characteristics of the Respondents}

From the survey result, majority of the respondents which is about $91 \%$ of the respondents, are male headed and the rest $9 \%$ are female headed. Around $22 \%$ of the female headed and $21 \%$ male headed households $(\mathrm{HH})$ were adopters but the chi-square value is insignificant (Table 2). The HH's average age was 40.45 years while the mean age for adopters and non-adopters were 43.35 and 39.86 respectively with significant mean difference at $5 \%$. The result shows that the beekeepers in the study areas getting older and more resources are in the hands of older farmers. The increase in adoption of technology with age may be due to the reason that most resources are in the hands of older and most young farmers have no enough back yards for beekeeping and are living around the town in most cases. Total average family size of sample respondents was 7.45 and it was 7.71 and 7.38 persons for adopters and non adopters respectively (Table 1 ).

Farming experience is one of the variables that was considered but it was found to be insignificant in affecting the adoption of the technology under consideration but with slight difference between mean of the adopters (22.84) and non-adopters (30.20) years. Educational background of household head was also found to be significant (Table 2).

\subsection{Resource Ownership and Income Sources of the Sample Households}

Resource ownership of the household is one of the determinant factors in adoption of a given technology. In this study the house type owned by the households, livestock possession, land holding, total bee colony possession, and others were considered for their effect on adoption probability. Accordingly, house type possessed by $\mathrm{HH}$ was found to be one of the significant factors where, the chi-square value is found to be significant at $1 \%$ probability level.

Farm animals have crucial roles in the rural economy. In general, they are sources of draught power, food such as milk and meat, cash, and means of transport both for human beings and agricultural produces. In addition to these, animal dung is used as fuel and organic fertilizer. Moreover, in the study area, farm animals are used as a measure of wealth. The household average tropical live stock unit was 11.00TLU with 14.20 (1.33) TLU and 10.10 (0.59) TLU for adopters and non-adopters respectively and mean difference significant at 5\% probability level.

In addition to this, oxen possession was also found to be more affecting factor for adoption of technology which is significant at $1 \%$. Similarly, farmers having more farm land adopted the technology in a better way. The result from Table 1 shows that the mean land holding for adopters and non-adopters were 4.98 ha and 3.29 ha respectively with mean difference significant at $1 \%$ probability level. And similarly, even though it is not statistically significant, the mean house stead (back yard) land which is in most cases used for beekeeping purposes was found to be larger for adopters which is 0.31 hectare and 0.30 hectare while the combined mean was found 
Table 1. Demographic and socioeconomic characteristic of respondents (continuous variables).

\begin{tabular}{|c|c|c|c|c|}
\hline & \multicolumn{4}{|c|}{ Mean } \\
\hline & $\underline{\text { Adopters }}$ & Non-Adopters & Combined & t-value \\
\hline Age & $44.27(1.75)$ & $39.55(0.85)$ & $4.59(0.78)$ & $2.55^{* *}$ \\
\hline Family size & $7.78(0.50)$ & $7.36(0.23)$ & $7.45(0.21)$ & 0.85 \\
\hline Farming experience & $24.04(1.81)$ & $29.94(10.04)$ & $28.66(7.84)$ & 0.31 \\
\hline Land holding & $4.98(0.60)$ & $3.29(0.17)$ & $3.66(0.19)$ & $3.78^{* * *}$ \\
\hline House stead land & $0.31(0.04)$ & $0.30(0.02)$ & $0.31(0.01)$ & 0.076 \\
\hline Land under beekeeping & $0.01(0.005)$ & $0.002(0.001)$ & $0.004(0.001)$ & $2.31^{*}$ \\
\hline Livestock (TLU) & $14.20(1.33)$ & $10.10(0.59)$ & $11.00(0.56)$ & $3.09^{* *}$ \\
\hline Bee colony & $9.78(2.24)$ & $4.76(0.40)$ & $5.86(0.59)$ & $3.58^{* * *}$ \\
\hline Market access (main) & $12.27(1.20)$ & $12.33(0.65)$ & $12.32(0.57)$ & 0.05 \\
\hline Distance from DU & $3.11(0.33)$ & $2.65(0.18)$ & $2.75(0.16)$ & 1.21 \\
\hline Distance to main road & $4.02(0.56)$ & $4.06(0.33)$ & $4.05(0.28)$ & 0.06 \\
\hline Nearest market access & $4.24(0.46)$ & $3.80(0.23)$ & $3.9(0.21)$ & 0.88 \\
\hline Annual honey production & 122.51 (39.69) & $24.99(2.04)$ & $46.36(9.14)$ & $4.58^{* * * *}$ \\
\hline Annual honey sale & 4165.09 (939) & $965.86(114)$ & $1666.89(238)$ & $5.92^{* * *}$ \\
\hline Honey production/local hive & $3.64(0.63)$ & $5.55(0.23)$ & $5.13(0.23)$ & $3.53^{* *}$ \\
\hline Live Stock sale & 3416.36 (613) & $2683.55(282)$ & $2844.13(258)$ & 1.18 \\
\hline Crop sale & $19497.45(3836)$ & 8794 (912) & 11139 (1131) & $4.03^{* * *}$ \\
\hline Annual nonfarm income & 3428.36 (929.57) & $1176(221)$ & $1669.39(272)$ & $3.50^{* *}$ \\
\hline Oxen number & $4.25(0.35)$ & $2.80(0.13)$ & $3.12(0.13)$ & $4.75^{* * *}$ \\
\hline Total annual income & 30507.27 (4495) & 13619 (1151) & $17320(1400)$ & $5.25^{* *}$ \\
\hline Share of honey sale & $0.181(0.027)$ & $0.11(0.010)$ & $0.124(0.01)$ & $2.96^{* *}$ \\
\hline Honey harvest/modern hives & $19.77(1.00)$ & - & & - \\
\hline Share of crop & $0.562(0.04)$ & $0.62(0.02)$ & $0.61(0.02)$ & 1.31 \\
\hline Share of LS & $0.15(0.026)$ & $0.193(0.014)$ & $0.183(0.012)$ & 1.52 \\
\hline Share of nonfarm income & $0.11(0.025)$ & $0.081(0.013)$ & $0.087(0.012)$ & 0.97 \\
\hline
\end{tabular}

***, **, and * show the level of significance at 1, 5 and 10\%; The numbers in brackets are standard errors of mean; Source: own survey result.

to be 0.31 hectare (Table 1). The size of land used for the purpose of beekeeping was another variable that affect the adoption probability and in this case adopters of modern beehive allocated more land for beekeeping purpose. Accordingly, adopters allotted 0.01 ha while non adopters allotted 0.002 ha of land.

Crop production, livestock rearing, non farm income sources like pity trade, and others like flour grain mill and beekeeping are main sources of income in the study areas. The major income share of the sampled households comes from the sale of crop which accounts for about $61 \%$ of total income followed by livestock and livestock output sale which is around $18 \%$ of the income share (Table 1). When we see contribution of income by different sources of HHs among adopters and non adopters, share of sale of honey for adopters group is significantly greater than that of non adopters group with t-value significant at $5 \%$ probability level (Table 1).

\subsection{Access of Sample Households to Different Service Providing Centers and Sources of Modern Beehives for Beekeepers}

There are different service providing centers to the beekeepers (farmers) of which their impact on modern bee 
Table 2. Demographic and socioeconomics characteristics of respondents (Categorical and Nominal variables).

\begin{tabular}{|c|c|c|c|c|c|c|}
\hline & & Adopter & Non-adopters & Total & $\chi^{2}$ & Asymp. Sig. \\
\hline \multirow[t]{2}{*}{ Sex of respondents: } & Male & 50 & 178 & 228 & 0 & 0.98 \\
\hline & Female & 5 & 18 & 23 & & \\
\hline Credit use & Yes & 6 & 35 & 41 & 1.52 & 0.22 \\
\hline (Formal) & No & 49 & 161 & 210 & & \\
\hline Credit Use & Yes & 16 & 59 & 75 & 0.021 & 0.89 \\
\hline (Informal) & No & 36 & 140 & 176 & & \\
\hline \multirow[t]{4}{*}{ Marital status } & Single & 3 & 11 & 14 & 1.44 & 0.7 \\
\hline & Married & 5 & 277 & & & \\
\hline & Divorced & 0 & 1 & 1 & & \\
\hline & Widowed & 0 & 4 & 4 & & \\
\hline \multirow[t]{6}{*}{ Educational } & 1 Illiterate & 8 & 32 & 40 & 10.41 & $0.065^{*}$ \\
\hline & $2 \mathrm{read} /$ write & 8 & 18 & 26 & & \\
\hline & 3 primary & 14 & 79 & 93 & & \\
\hline & 4 secondary & 18 & 58 & 76 & & \\
\hline & 5 post second & 6 & 9 & 15 & & \\
\hline & 6 others & 1 & 0 & 1 & & \\
\hline \multirow[t]{3}{*}{ House type } & 1 thatched roof & 5 & 86 & 91 & 26.75 & $0.000^{* * * *}$ \\
\hline & 2 corrugated iron & 11 & 11 & 22 & & \\
\hline & 3 both & 36 & 102 & 139 & & \\
\hline \multirow[t]{5}{*}{ Extension contact } & 1 Every day & 13 & 38 & 51 & 2.71 & 0.57 \\
\hline & 2 every week & 27 & 82 & 109 & & \\
\hline & 3 every month & 6 & 23 & 29 & & \\
\hline & 4 sometimes & 8 & 47 & 55 & & \\
\hline & 5 no contact & 1 & 6 & 7 & & \\
\hline \multirow[t]{2}{*}{ Train on Modern BH } & yes & 25 & 23 & 48 & 31.57 & $0.000^{* * * *}$ \\
\hline & No & 30 & 173 & 203 & & \\
\hline \multirow[t]{2}{*}{ Demonstration on $\mathrm{MBH}$} & yes & 41 & 59 & 100 & 35.4 & $0.000^{* * * *}$ \\
\hline & No & 14 & & 137 & & 151 \\
\hline
\end{tabular}

Source, own survey result.

hive can be observed directly or indirectly. Of these factors, access to main market, access to development unit and distance to main road are the major ones. In addition to these, access to credit service providing centers were also considered and access to formal credit providers have no significant effect on adoption probability while the informal one has effect. This is may be due to the fact that there is less attention given to the sector which geared all the credit from formal sources towards other sectors such as the purchase of seed and fertilizer and other livestock sectors like small scale fattening as it can be seen from Table 3. Furthermore, the extension contact rate did not have any significant impact on the adoption probability of modern beehive and this is may be due to the fact that most of the time development agents do not consider the beekeeping activity in their day to day activities which may be due to policy focus area (Table 2). But demonstration and training given on modern beehive utilization, managements like harvesting, wax stumping and etc have significant impact (chi-square sig. at 1\% (Table 2)). 
Table 3. Honey and honey products marketing and related problems of the respondents.

\begin{tabular}{cccc}
\hline No. & Description & Number of respondents' & Percent \\
\hline 1 & Sell at village & 212 & 84.5 \\
2 & Sell at local market & 178 & 70.9 \\
3 & Sell to Cooperatives & 8 & 3.2 \\
4 & Sell to local honey collectors (Traders) & 109 & 56.6 \\
5 & Sell to consumers & 248 & 98.8 \\
\hline
\end{tabular}

Source: own survey.

Beekeepers owned their modern beehives from different sources. The majority of the beekeepers bought their modern beehives from the former Asela rural technology promotion center, the current Asela Agricultural mechanization research center which accounts for 48 (81.36\%) of the users and only five (8.5\%) bought from microenterprises.

\subsection{Hive Product Marketing and Related Problems}

Even though there is almost no respondent who reported the problem of marketing and market access problem during survey, there is no broad option of market in the study areas. As it can be understood from the survey result, the major market destinations of the areas are village marketing among rural households, local markets, and cooperatives (with very small percent 3.2\%). The beekeepers have no specific customer who buys their produce and they sell to local honey collectors (traders), consumers both from rural and urban areas and local "tej" makers. Accordingly, $84 \%, 70 \%$ and $3.2 \%$ of the respondents sell their honey at village, local markets and to honey and honey product cooperatives respectively. Similarly, 98.8\%, 56.6\% and 30.3\% of the respondent's produces were sold to consumers, to local honey collectors (traders) and local "tej" makers respectively (Table 3).

\subsection{Modern Beehive Adoption}

In general out of 251 respondents, only 55 or around 22\% are adopters of modern beehive and the rest 196 (78\%) are non adopters. Out of the total respondents, 59 (nearly 24\%) of the respondents experienced the use of modern beehives but $4(6.80 \%)$ of them dis-adopted the technology because of different reasons, mainly due to absence of accessories $4(100 \%)$ and other related reasons like lack of skill, and bee absconding problems (Table 4).

Information sources evidences that remote districts have good potential of beekeeping as most of the time they do have large amount of natural forests. But from the above Table 5 we can see that as we move from the center, Asela, the number of modern beehive that beekeepers are using is decreasing and this potential resource is not being utilized by modernizing beekeeping technologies. The three districts having better modern beehives, Lemu-Bilbilo, Arsi-Robe and Lode-Hetosa are all those districts found within the radius of $100 \mathrm{~km}$ and less from Asela. While Chole and Merti and those found at far (remote) distance from the Center.

\subsection{Major Constraints of Beekeeping Sub Sector in the Study Area}

A number of beekeeping subsector constraints were assessed in this study for the areas. In general the major constraints were hypothesized and the respondents were requested to rank those constraints according to their perception (Table 6). Accordingly, chemicals like herbicides and different pesticides application for crop production was ranked by $61 \%$ of the respondents as the first constraints to expand or even to continue with the same rate of the current beekeeping activities in the study areas. Predators like ants, spiders, lizards, and different birds were ranked as the second most constraints by about $50 \%$ of the respondents while lack of skill and knowledge of modern beehives manage was the third major constraint. The fourth, fifth and sixth major constraints were lack of necessary accessories (like extractor, wax stumpers, bee smokers), lack of additional bee feed (forages), and lack of capital respectively. In this regard change in weather conditions as there is high deforestation, affects beekeeping by reducing flora.

Beekeepers of the area suggested a solution for each problem which can be applied by different concerned 
Table 4. Reasons for dis-adopting modern beehive.

\begin{tabular}{ccc}
\hline No. & Reasons & Respondents in number and percent \\
\hline 1 & 1. Absence of beehive accessories & $4(100 \%)$ \\
2 & 2. Lack of skill on managing modern beehives & $3(75 \%)$ \\
3 & 3. Bee absconding from hive & $1(25 \%)$ \\
4 & 4. Market problem for hive product & $1(25 \%)$ \\
\hline
\end{tabular}

Source: own survey 2009.

Table 5. Beehives adoption by district.

\begin{tabular}{|c|c|c|c|c|}
\hline & \multirow[t]{2}{*}{ Districts } & \multicolumn{2}{|c|}{ Continue using modern beehive } & \multirow[t]{2}{*}{ Total } \\
\hline & & No & Yes & \\
\hline 1 & Aminga & 32 & 8 & 40 \\
\hline 2 & Bele & 30 & 6 & 36 \\
\hline 3 & Chole & 36 & 1 & 37 \\
\hline 4 & Lemu-bilbilo & 17 & 14 & 31 \\
\hline 5 & Lode-hetosa & 23 & 11 & 34 \\
\hline 6 & Merti & 33 & 1 & 34 \\
\hline \multirow[t]{2}{*}{7} & Arsi-robe & 25 & 14 & 39 \\
\hline & Total & 196 & 55 & 251 \\
\hline
\end{tabular}

Source: AAMRC survey, 2009.

Table 6. Major apiary constraints of the study areas.

\begin{tabular}{ccc}
\hline & Rank of the constraint & \% of respondents given the rank \\
\hline 1 & Chemical application (herbicides and pesticides) & $61 \%$ \\
2 & Bee predators & $50 \%$ \\
3 & Lack of knowledge and skill on modern beehives & $40 \%$ \\
4 & Lack of modern beehive accessories & $35 \%$ \\
5 & Lack of bee forage (additional bee feeds) & $32 \%$ \\
6 & Lack of capital & $49 \%$ \\
\hline
\end{tabular}

Source: own survey, 2002.

stakeholders. For example, majority of the farmers suggested timely application of herbicides before the flowering of crops and weeds. This can minimize the death of honey bee as bees would not go for the search of their pollen while there is no flower on the crop/weed. For the second problem proper beehive management skills and awareness must be created through practical training specially for the protection of different ants, lizards and spiders. But there are seasonal birds which harm the hive seriously and very difficult for the beekeepers to protect their hives. But some beekeepers tried their best by availing some feeds and water around the hive so that the bees should not go far and escape from such bee eating birds.

The gap in lack of awareness and skill can be fulfilled by training by beekeeping experts at different levels. Lack of accessories, the fourth major problem should be solved through availing such accessories through credit facility, organizing and awareness creation of beekeepers to buy those technologies in group, availing enough number of technologies at least at Peasant Association level for borrowing and so on. It is because of this problem most beekeepers who, even started using modern beehive, dis-adopted the technology and most beekeepers miss at least one season harvest. Shortage of bee forage was the last ranked constraint which is the major cause for bee swarm absconding especially during the dry season (Table 7). 
Table 7. Reasons for not adopting modern beehives along districts.

\begin{tabular}{cccccccccc}
\hline No. & Reason for not using & \multicolumn{7}{c}{ Districts } \\
\hline 1 & Lack of awareness & Amigna & Bele & Chole & L/Bilbilo & L/Hetosa & Merti & A/Robe Total (\%) \\
2 & Lack of capital & 25 & 19 & 26 & 9 & 20 & 25 & 2520 & $144(57.37)$ \\
3 & Non availability & 16 & 18 & 8 & 10 & 3 & 6 & 16 & $77(30.68)$ \\
4 & Others & 11 & 21 & 31 & 6 & 10 & 12 & 14 & $39(15.54)$ \\
5 & & & 3 & 1 & 0 & 0 & 0 & 0 & 0 \\
\hline
\end{tabular}

Source: AAMRC survey, 2009.

\subsection{Modern Beehives Utilization Problems}

Table 7 shows the modern beehive utilization constraints by districts and from the survey result table it is clear that lack of awareness about the benefits of modern beehives over the local ones was found to be the most prominent (Conspicuous) reason/bottleneck for non utilization of modern beehives which is claimed by about $57 \%$ of the respondents. Lack of enough capital for investment and non availability of the technologies around the areas were the second and third problems in technology adoption of the areas (Table 7).

\subsection{Major Beekeeping Practices and Labor Division in Beekeeping by Sample Respondents}

\subsubsection{Labor Division in Beekeeping, Honeybee Feeding and Bee Forage Planting Practices}

From the survey result it can be seen that beekeepers are taking different measures in order to feed their honey bees' swarm especially during the dry season when it becomes difficult for workers bees to find flower from the forest. Therefore, majority of beekeepers (around 78\%) feed their honey bee by providing some feed substances like sugar, flour of beans, chickpea and peas and water while considerable number of beekeepers (around 31\%) plant flowering plants or trees around their home which flowers during dry season (Table 8).

There are different activities to be done in beekeeping business like: swarm catching, transferring, hive inspection, honeybee feeding, honey harvesting, honey extraction and marketing. In this study area majority of management of beehive is mostly done by husbands (about 93\%). It can be understood that in most modern beehive adopters cases, the management is being done by females (wives) that is 13 females out of 55 adopters participated in beehive management practices (Table 8). This shows that how adopting modern beehive break the status quo that beekeeping is job of males and it also shows that modern beehive management is easier than local hive's management for female. But activities like hive inspection honey bee feeding, and marketing are done by females, mostly by wives.

\subsubsection{Honey Harvesting, Hive Shading Construction, Wax Stumping and Predators Protection Practices}

As it is known the traditional way of beekeeping does not need any special method of honey harvesting mechanism and the beekeepers simply take away the crude honey and sell including its comb most of the time without extracting or extract the honey using their hands. Mostly the comb is extracted as a wax and used for sale by "tej” makers. But modern beehive adopters use modern honey extractor to harvest honey. As it is discussed above lack of modern beehive accessories were the most problem in the area and majority of the adopters (more than 67\%) get honey extractor from bureau livestock development and marketing agency by borrowing and only $5.45 \%$ of them have their own extractor (Table 9).

Regarding hive shading construction practices all non adopters have their hives hung under their roofs and no special shade construction was needed. But for adopters, almost all of them constructed shade at least during the summer season to protect their hive from the damage by rain. In this regards hive baiting, is the most serious problem for traditional hive type because traditionally most beekeepers hung their hives on trees in the forest. Colony absconding was found to be more serious problem for local (traditional) beehives type because hive inspection, cleaning and protection from different predators is challenging as the hives are in the forest and even those in the compound of the beekeepers are not kept in well protected areas. 
Table 8. Honey bee feeding mechanism and labor division in beekeeping practice.

\begin{tabular}{|c|c|c|c|c|c|}
\hline \multicolumn{3}{|c|}{ No. Feeding mechanism } & \multicolumn{2}{|c|}{ respondents' percent } & \multirow{2}{*}{$\begin{array}{r}\% \text { of "yes' } \\
\text { of total }\end{array}$} \\
\hline & & & Adopters & Non-Adopters & \\
\hline \multirow[t]{2}{*}{1} & Planting bee forage & Yes & 21 & 56 & $30.70 \%$ \\
\hline & & No & 34 & 140 & \\
\hline \multirow[t]{2}{*}{2} & Providing other feed like sugar and flour & Yes & 47 & 149 & $77.70 \%$ \\
\hline & & No & 8 & 47 & \\
\hline \multirow[t]{2}{*}{3} & Take no action to feed honey bee & Yes & 4 & 34 & $15.10 \%$ \\
\hline & & No & 51 & 162 & \\
\hline \multirow[t]{2}{*}{4} & $\begin{array}{c}\text { Transfer hive to other areas during } \\
\text { dry seasons }\end{array}$ & Yes & 0 & 5 & $2 \%$ \\
\hline & & No & 55 & 191 & \\
\hline \multirow[t]{2}{*}{5} & Husband manage & Yes & 53 & 180 & 92.8 \\
\hline & & No & 2 & 16 & \\
\hline \multirow[t]{2}{*}{6} & Wife manage & Yes & 13 & 37 & 19.9 \\
\hline & & No & 42 & 159 & \\
\hline \multirow[t]{2}{*}{7} & Daughter manage & Yes & 0 & 6 & 2.4 \\
\hline & & & 55 & 190 & \\
\hline \multirow[t]{2}{*}{8} & Son manage & & 3 & 9 & 4.8 \\
\hline & & & 52 & 187 & \\
\hline
\end{tabular}

Source: own survey result.

Table 9. Sources of honey extractor and wax stumpers for modern beehive adopters.

\begin{tabular}{cccc}
\hline No. & Source of extractor and wax stumper & Extractor & Stumper \\
\hline 1 & Having own & $3(5.45 \%)$ & $2(3.64)$ locally made \\
2 & Borrowing extractor from bureau of agriculture & $37(67.27)$ & $50(90.91)$ \\
3 & Borrowing extractor from NGOs & $2(3.64)$ & $3(5.45)$ \\
4 & Have extractor in group & $7(12.73)$ & 0 \\
\hline
\end{tabular}

Source: own survey data.

\subsection{Sensitivity Analysis of Adoption Level on Volume of Production and Income from Hive Product}

According to the survey result, the average productivity of the modern beehives and local beehives in the study area was found to be $19.77 \mathrm{~kg} /$ hive and $5.13 \mathrm{~kg} /$ hive with 1.00 and 3.65 standard error respectively. The total number of local type of beehives (bees colonized by local beehive type) possessed by interviewed beekeepers was found to be 1201 while the total number of modern beehives (bees colony colonized in modern beehives) was found to be 279 hives which shows that the adoption rate is $21.95 \%$ and If we increase the adoption rate and shift the number of local beehives by $50 \%$ i.e., if number of local beehives decreases by 600 and that of modern hives increases by the same amount, the amount of honey harvest will increases by 11,862 kg which is about $5700 \mathrm{~kg}$ more than the total honey that beekeepers can get from the whole 1201 local hives (Table 1). If we take the average price of the honey per kilogram of money at the time of survey which was $50 \mathrm{Birr} / \mathrm{kg}$, the total income also could increase by 285043.5 Birr if adoption rate increased by $50 \%$.

\subsection{Analysis of Determinants of Adoption of Modern Beehives}

A total of fourteen (14) explanatory variables were included in econometric model (logit model) analysis. The 
overall significance of the model is measured by the Wald statistics which follows a chi-squared distribution with 14 degree of freedom. The hypothesis that all the coefficients except the constant are zero $(0.0000)$ is rejected as equation is significant at 1 percent significance. This implies that significant proportion of the dependent variable is explained by independent variables. The likelihood-ratio chi-squared had a value of 94.94 with Pseudo- $\mathrm{R}^{2}$ of about 36 percent which implies that about 36.52 percent of the variation in the adoption of the modern beehives in the zones is explained by the variables considered (Table 10).

Heteroscedasticity problem was corrected by the use of command robust in Stata (version 10). The multicollinearity problem was checked by using VIF (Variable Inflation Factor) for continuous variables and CC (Contingency Coefficient) for dummy variables and there is no series problem (Table 11). By rule of thumb, there is no problem of multicollinearity as CC was found to be less than 0.8 while VIF found was less than 10 . Where, according to Maddala (1992) and Gujarati (2004) VIF can be defined as: VIF (xi) $=\frac{1}{1-R^{2}}$

where, $R^{2}$ is the squared multiple correlation coefficient between $\mathrm{X}_{\mathrm{i}}$ and the other explanatory variables.

From the result of logit model, important variables that best explained the adoption of modern beehives in the study area are discussed below.

From the logit model result in Table 12 it is revealed that the increase in age of HHs head increase the probability of adoption significantly. The change in age by a unit has probability of changing adoption rate by 0.33645 percent. Size of farmyard that HHs possessed is an important variable that affect adoption of the modern beehive positively. Result from logit model shows that the variable is significant at $10 \%$ probability level and the marginal effect coefficient after logit model revealed that change of size of farm yard by a unit affects the probability of adoption by 18.51 percent (Table 13). Number of local (traditional) beehives (under square root) has negative significant (10\%) effect on adoption probability of modern beehives. The change in square roots of number of local beehives by one unit, have probability of changing adoption probability by 3.97 percent negatively. The probable explanation may be that once they adopted the local one unless they are trained and well informed about the modern one, they may think that it is enough for them. Participation on modern beekeeping technologies training and demonstration of modern beekeeping both has positive significant effect on adoption probability at $1 \%$ and $5 \%$ probability level. The change from participant to nonparticipant on training and demonstration will change probability of adoption by 22.04 and 14.45 percent respectively. Types of house whether it is thatched roof or corrugated iron is significant variable. The result revealed that the change from

Table 10. Measurements of goodness of fit from the binary logit model.

\begin{tabular}{ccc}
\hline Logistic regression & Number of obs. & 251 \\
\hline & LR chi2 (14) & 82.38 \\
Log likelihood $=-83.78352$ & Prob. $>$ chi2 & 0 \\
\hline
\end{tabular}

Source: AAMRC survey, 2010.

Table 11. Results of multicollinearity test: Variance inflation factor for the continuous explanatory variables.

\begin{tabular}{ccc}
\hline Variable & VIF & 1/VIF \\
\hline Square roots of landholding & 2.24 & 0.447285 \\
Square roots of livestock in TLU & 2.1 & 0.475817 \\
Family labor in man-equivalent & 1.8 & 0.555848 \\
Age & 1.75 & 0.570535 \\
Farmyard & 1.25 & 0.797457 \\
Natural logarithm of income & 1.25 & 0.798316 \\
Square roots of number of local hive & 1.05 & 0.949861 \\
\hline
\end{tabular}

Source: own survey result, 2010. 
Table 12. Results of multicollinearity test: Contingency coefficient for dummy variables.

\begin{tabular}{|c|c|c|c|c|c|c|c|}
\hline & Sex & Nonfarm & Trainbee & Htype & Demo & Educ & Crdtother \\
\hline Sex & 1 & & & & & & \\
\hline Participation on Nonfarm income & -0.0123 & 1 & & & & & \\
\hline Participation on beekeeping training & 0.0347 & 0.1112 & 1 & & & & \\
\hline House type owned & -0.0477 & -0.0385 & -0.1591 & 1 & & & \\
\hline Participation on Demonstration of beekeeping & 0.0328 & 0.1856 & 0.2968 & -0.1567 & 1 & & \\
\hline Educational background of $\mathrm{HH}$ & -0.0656 & -0.0295 & -0.0004 & 0.0642 & 0.0294 & 1 & \\
\hline Credit use from informal sources & 0.0867 & 0.1056 & -0.0091 & 0.0327 & 0.1621 & 0.053 & 1 \\
\hline
\end{tabular}

Source: AAMRC survey, 2010.

Table 13. Results of binary logit estimation for adoption of modern beehives.

\begin{tabular}{|c|c|c|c|c|}
\hline Variables & Coef. & Std. Err. & $\mathbf{P}>\mathbf{z}$ & $d y / d x$ \\
\hline Age & 0.0349092 & 0.0199142 & $0.080^{*}$ & 0.0033645 \\
\hline Sex & -0.280984 & 0.8082853 & 0.728 & -0.0296266 \\
\hline Participation on Nonfarm & 0.8902084 & 0.4277984 & $0.037^{*}$ & 0.100252 \\
\hline Credit use from informal sources & -0.0459638 & 0.4292751 & 0.915 & -0.0043981 \\
\hline Farmyard land size & 1.912804 & 1.133338 & $0.091^{*}$ & 0.1843533 \\
\hline Training on beekeeping & 1.652521 & 0.4365281 & $0.000^{* * *}$ & 0.2279065 \\
\hline House type owned & -1.668666 & 0.5002083 & $0.001^{* *}$ & -0.1414244 \\
\hline Participation on beekeeping demonstration & 1.359769 & 0.4463175 & $0.002^{* *}$ & 0.1495546 \\
\hline Family labor in Man equivalent & -0.0993451 & 0.1068699 & 0.353 & -0.0095747 \\
\hline Square root of number local beehive & -0.4228914 & 0.2810261 & 0.132 & -0.0407577 \\
\hline Square root of landholding & 0.6768429 & 0.3792706 & $0.074^{*}$ & 0.0652331 \\
\hline Square root of livestock in TLU & 0.0152933 & 0.2399343 & 0.949 & 0.0014739 \\
\hline Natural logarithm of income & 0.3240982 & 0.2674908 & 0.226 & 0.0312361 \\
\hline Educational status of $\mathrm{HH}$ & -0.6572071 & 0.5408751 & 0.224 & -0.0753804 \\
\hline _cons & -5.789139 & 2.646268 & $0.029^{*}$ & \\
\hline
\end{tabular}

Marginal effects after logit; $\mathrm{Y}=\operatorname{Pr}($ usingnow $)$ (predict) $=0.10805429 ;\left(*^{*}\right)(*) \mathrm{dy} / \mathrm{dx}$ is for discrete change of dummy variable from 0 to 1 , $*=$ significant at 10 percent; $* *=$ significant at 5 percent; $* * *=$ significant at 1 percent.

corrugated iron to thatched roof house type has negative effect on adoption probability which is significant at $5 \%$ probability level. The marginal effect revealed that, the change from corrugated to thatched roof house type will change the probability of adoption by 14.59 percent. The possible explanation could be the fact that adopters are getting sufficient income from sell of hive products to improve their life standards. Participation of beekeepers household head on nonfarm income activities is also significant (10\% probability). The change from participant to nonparticipant of a given adopter will reduce probability of adoption by 10.34 percent (Table 13).

\section{Conclusion and Policy Implications}

This paper examined the adoption rate and determinants of decision's of beekeepers to adopt modern beehives in Arsi zone. Although the government of Ethiopia gives great attention to the beekeeping sub sector to promote modern beekeeping technologies, but rate of adoption and dissemination of the technology is found to be very minimal.

Adoption of modern beehives has very significant effect on hives productivity as it can be seen clearly from 
sensitivity analysis part of the document and beekeeping can also be used as one of income diversifying mechanism and even can be the basic occupation for most rural dwellers. But the number of beekeepers started using modern beehives (numbers of adopters) is almost insignificant and they are still using local beekeeping technologies. The main determinants of adoption are farmyard size, number of local hives beekeepers possessed, training provision and participation on training, wealth status of beekeepers, and participation of beekeepers on nonfarm income sources. Even though almost all beekeepers know the presence of modern beehives, they did not adopt because of different reasons. For instance, the result of survey from descriptive statistics shows that beekeepers do not have enough awareness on advantages of the technologies that enable them to use modern beehives. Lack of capital and non availability of modern beehives and its packages accessories (honey harvesting and processing equipments like wax-stumper, queen excluders, honey extractor, bee smoker and others) around the beekeepers are also among the other major problems. As beekeeping is not as such commercialized there is no such huge production per beekeeper in these areas, the whole bee products are sold around their own vicinity and no report of transportation difficulties problem. The result of econometric model also clearly indicates that participation of beekeepers on demonstration and training of modern beehives were among the most significant determinants of adoption. Therefore, based on the above conclusion the following policy implications and area specific solution can be drawn:

- Provision of different information towards increasing or improving the saving capacity or culture of beekeepers as saving increases the wealth of beekeepers and the wealth category of the beekeepers in turn have effect on determining adoption probability of modern beehives.

- Provision of adequate and relevant agricultural extension services (such as training on modern beekeeping technologies and demonstration and beekeepers to beekeepers experience sharing) to beekeepers. Training should also be given by giving attention to wise way (timely application) of using different chemicals specially herbicides to minimize the death of honey bees.

- Provision of credit services to beekeepers to widen the financial bases of poor beekeepers. Beekeepers can use the loan to buy modern beehives and access to modern beehives accessories like honey extractor, smokers, brush, gloves, wax stumper and others. Baiting

- Facilitating access to modern beehives and its accessories especially honey extractor and wax stumper which can increase beehives productivity which in turn can positively affects beekeeper's capacity of adoption.

\section{References}

[1] Kassaye, A. (1990) The Honeybees (Apis Mellifera) of Ethiopia. A Morphometric Study. M.Sc. Thesis, Agricultural University of Norway, As, Norway.

[2] Gebreyesus, M. (1976) Practical Aspects of Bee Management in Ethiopia. Proceedings of the 1st International Conference on Apiculture in Tropical Climates, London, 69-78.

[3] Holeta Bee Research Center (2004) Beekeeping Training Manual. Holeta, Ethiopia.

[4] Feder, L., Just, R.E. and Zilberman, O. (1985) Adoption of Agricultural Innovationin Developing Countries: A Survey. Economic Development and Cultural Change, 32, 255-298. http://dx.doi.org/10.1086/451461

[5] Rogers, E.M. and Shoemaker, F.F. (1971) Communication of Innovation: A Cross-Cultural Approach. 2nd Edition, The Free Press, New York.

[6] Ray, G.L. (2001) Extension Communication and Management. Naya Prokash, Calcutta, 145-162.

[7] Salim, M. (1986) Rural Innovation in Agriculture. Chugh Publications, New Delhi.

[8] Ehui, S.K., Lynam, J. and Okike, I. (Eds.) (2004) Adapting Social Science to the Changing Focus of International Agricultural Research. Proceedings of a Rockefeller Foundation. ILCA Social Science Research Fellows Workshop Held at ILCA, Addis Ababa, 14-18 November 1994, 189-203.

[9] Olana, G. (1993) Farmers Response to New Coffee Development Technologies and Factors Influence It: The Case of Small Farmers in Ghimbi CIPA, Wollega. Unpublished M.Sc. Thesis, Haramaya University, Dire-Dawa.

[10] Croppenstedt, A. and Demeke, M. (1996) Determinants of Adoption and Levels of Demand for Fertilizer for Cereal Growing Farmers in Ethiopia. Working Paper No. 96, Center for the Study of African Economies, Oxford University of Oxford.

[11] Naseem, A.C. (1995) Macro Trends and Determinants of Fertilizer Use in Sub Saharan Africa. MSU International Dev. Paper US.

[12] Cramb, R.A. (2003) Processes Affecting the Successful Adoption of New Technologies by Smallholders. In: Hacker, 
B., Ed., Working with Farmers: The Key to the Adoption of Forage Technologies, ACIAR Proceedings No. 95, ACIAR (Australian Centre for International Agricultural Research), Canberra, 11-22.

[13] Gorfu, M. (2005) Adoption and Profitability of Kenyan Top Bar Hive Beekeeping Technology: A Study in Ambasel Woreda of Ethiopia. Unpublished M.Sc. Thesis, Haramaya University, Dire-Dawa.

[14] Abebe, W., Puskur, R. and Karippai, R.S. (2008) Adopting Improved Box Hive in Atsbi Wemberta District of Eastern Zone, Tigray Region: Determinants and Financial Benefits. IPMS (Improving Productivity and Market Success) of Ethiopian Farmers Project Working Paper 10. ILRI (International Livestock Research Institute), Nairobi, 30 p.

[15] Ethio-Italian Development Project (2002) Atlas of Arsi Zone. Arsi Agricultural and Rural Development Bureau, Assela, Ethiopia.

[16] The National Regional Government of Oromia, Bureau of finance and Economic Development-Regional Statistics (2012). http://www.oromiabofed.org/

[17] Gebremariam, H. (1992) Availability and Use of Seed in Ethiopia. Program Support Unit, Canadian International Development Agency (CIDA), Addis Ababa.

[18] Aldrich, J.H. and Nelson, F.D. (1984) Linear Probability, Logit and Probit Model: Quantitative Application in the Social Science-Sera Miller McCun. Sage pub. Inc, University of Minnesota and Iola, London.

[19] Gujarati, D.N. (1995) Basic Economics. 3rd Edition, McGraw-Hill, Inc., New York.

Appendix I. Conversion factor used to estimate TLU.

\begin{tabular}{ccc}
\hline No & Types of Animals & TLU \\
\hline 1 & camels & 1.25 \\
2 & cattle & 1.00 \\
3 & sheep & 0.10 \\
4 & goats & 0.10 \\
5 & horses & 0.80 \\
6 & mule & 0.70 \\
7 & Donkey & 0.50 \\
8 & Chickens & 0.01 \\
\hline
\end{tabular}

Source: FAO, 1987; FAO, 1986b.

\section{Appendix II. Conversion factors to drive man-equivalent.}

\begin{tabular}{ccc}
\hline Age group (yrs) & Male & Female \\
\hline$<10$ & 0.0 & 0.0 \\
$10-13$ & 0.2 & 0.2 \\
$14-16$ & 0.5 & 0.4 \\
$17-50$ & 1.0 & 0.8 \\
$>50$ & 0.7 & 0.5 \\
\hline
\end{tabular}

Source: Stork, et al., 1991. 